\title{
Applied of Alternative Business Training Models through Environmental-Based Community Empowerment for Farmer Labor
}

\author{
Tenri Sau ${ }^{1}$, Gufran D. Dirawan², Ahmad Rifqi Asrib ${ }^{3}$ \\ ${ }^{1}$ Universitas Negeri Makassar \\ Universitas Puangrimanggalatung \\ Jln. Bonto Langkasa, Kampus Gunung Sari Baru \\ Email: tenrisau779 [AT] gmail.com \\ ${ }^{2}$ Universitas Negeri Makassar \\ Jln. Bonto Langkasa, Kampus Gunung Sari Baru \\ Email: gufrandarma [AT] unm.ac.id \\ ${ }^{3}$ Universitas Negeri Makassar \\ Jln. Bonto Langkasa, Kampus Gunung Sari Baru \\ Email: rifqiasrib [AT] unm.ac.id
}

\begin{abstract}
Agriculture is one of the fields that still dominates Indonesia as an agricultural country. As a substantial actor in agriculture, many farmers have not met their daily needs. This study examines the quality of alternative business training models for farmworkers using a community empowerment system. This study is part of research and development focused on product quality testing. The training model that the researcher has designed is then tested on validity, practicality, and effectiveness. The participants involved in this study were farm labourers in 2 sub-districts in Wajo Regency, South Sulawesi, Indonesia, namely Pammana and Tanasitolo sub-districts as many as 15 farm workers, two observers, and three agricultural experts. Furthermore, the instruments used in this study were: (1) validation sheet, (2) model implementation observation sheet, (3) farmworker response questionnaire, and (4) knowledge test. The data that has been collected is then analyzed quantitatively using SPSS 23.00 software. The study results show that the training model that this researcher has designed is valid, practical, and effective in increasing the knowledge of farmworkers and can be used for a broader range of users.
\end{abstract}

Keyword - Alternative Business, Community Empowerment, Research \& Development

\section{INTRODUCTION}

As one of the agricultural countries in Southeast Asia, it has enormous potential for natural resources. One of them is the farm sector, which is most of the population [1]. The extent of agricultural land in Indonesia is the most significant driving force for the nation's economy apart from the manufacturing sector. [2] confirmed that agriculture is still one of the top sectors besides trade and construction. This condition certainly brings a positive image of the Indonesian nation as an agricultural country with a high level of productivity.

According to [3] masyarakat miskin di Indonesia hingga tahun 2019 mencapai $12.6 \%$ di perdesaan dan $6.56 \%$ di perkotaan. the poor in Indonesia until 2019 reached $12.6 \%$ in rural areas and $6.56 \%$ in urban areas. Furthermore, BPS stated that $48.4 \%$ of the poor came from community groups who worked in the agricultural sector. This fact is corroborated by [4] study, which states that farmers are indeed synonymous with poverty. Even an analysis generalizes that poverty comes from farming communities in rural areas [5,6].

Wajo Regency is one of the regencies in South Sulawesi Province; Indonesia also has a large area of agricultural land. This district is the second district in South Sulawesi Province as a district that uses agricultural land extensively after Bone district. The paddy fields in this district are 100,354 ha and can produce 820,815 rice in 2017 [3]. This indicates that the agricultural potential in this district is quite significant and promising if developed properly.

This condition contradicts the welfare of farming communities that have low incomes [7]. In other words, the aspect of social welfare in the Wajo Regency has not been implemented thoroughly and optimally. Several factors cause why farmers are still not able to meet their daily needs. One of them is the focus of farmworkers who only focus on the results of their main activities without thinking about doing alternative businesses. This means that farmworkers have not developed 
themselves to increase their income outside of rice cultivation.

One way to provide a solution in this situation is to empower the community. Community empowerment can be understood as an effort to take over power to effectively change lives and the environment [8]. With community empowerment, community participation and community organizations are encouraged to improve the quality of life and social justice together [9].

With this foundation, researchers are interested in developing alternative business training models for farmworkers by utilizing community empowerment strategies related to environmental issues. Environmental issues are crucial issues that are an integral part of agriculture. Globally, it can be argued that increasing demand for agricultural products often goes against environmental protection goals [10]. The success of agriculture in achieving food security has resulted in severe environmental damage, damage to biodiversity, water quality, and others [11].

Several previous studies raised the theme of training for farmworkers. One of them is research conducted by [12]. The study found an increase in the knowledge of farmers who use smartphones as a source of agricultural information. Another study stated that education and training (education and training) affected increasing farmers' food crop production [13]. In addition, another study also stated that farmers could utilize rice waste through specific training to become husk charcoal [14].

There are still no researchers who use research and development designs in developing a specific community empowerment-based training model from these studies. For this reason, researchers are interested in developing an alternative business training model based on community empowerment and testing the quality of the training model. The formulation of the problem in this study is how the level of validity, practicality, and effectiveness of alternative business training models based on community empowerment increases farm workers' knowledge.

\section{LITERATURE REVIEW}

\subsection{Training Model}

In general, training is a program carried out in out-of-school education programs designed to provide knowledge and skills for individuals and groups [15]. The training is given to provide them with the tools, knowledge, and various skills they need in life at that time [16].

Training in this context is different from education in schools because the goals to be achieved are directed at adult learning. The theoretical basis for adult learning is a systematic theory that describes adult education through situational pathways and not in the learning process [17]. In conventional education, students are required to adapt to the established curriculum. For adults, the learning curriculum is built based on the needs and interests of the trainees [18].

Learning for adults will be effective if it involves an understanding of how adults learn best. Compared to children and adolescents, adults have special needs and requirements as learners [19]. In other words, the essential thing that is the source of the highest value in adult learning is the learning experience [20]. The learning experiences referred to here relate to the particular situations they experience, such as work, recreation, family life, community and others that require adjustment [21].

The training model is identical in meaning to the learning or teaching model. Each model should guide the instructor to help participants achieve the training objectives. [22] state that an analyzed learning model following the four core operational concepts of the model that characterize, namely: 1) syntax (sequence of teaching and learning activities); 2) social system (roles and relationships between participants and instructors); 3) the principle of reaction (the way the instructor perceives and responds to the participants to what is being done); 4) the support system (what requirements and support are needed outside the general technical facilities), and 5) the impact of learning and the impact of learning accompaniments.

\subsection{Alternative Business for Farmworkers}

Historically, farming activities were first carried out by women. This happened because of agricultural activities that started from the division of tasks between men and women. Women who accept the nature of raising children are required to provide food. It was from here that women began to learn how to grow crops. Based on the efforts of these women, a livelihood is created in the agricultural sector [23].

On the other hand, [24] said that farming is an integrated effort that aims to increase farmers' income to meet the needs of all their family members. Another definition is also put forward by [25], which describes that farming is an effort made by a farmer/group of farmers in allocating existing resources effectively and efficiently to obtain high profits at a specific time.

In simple terms, farming can be said as an effort made by a person or group of people related to agriculture. Agricultural 
activities consist of two systems, namely:

(1) an agricultural system with fields with the main production factor being only nature, always on the move looking for fertile land, and (2) a passive agricultural system in which the production factors are not only natural but include labour and capital. The second agricultural system has made efforts to fertilize, build embankments, terracing, and good soil management to realize a permanent agricultural system [23].

\subsection{Community Empowerment}

Empowerment comes from the word power which means power or power. The main idea of empowerment is the ability to make other people do what they want and be free from the desires and interests of these people [26]. In Indonesia, the term 'community empowerment' has begun to be used in general as everyday language along with the term poverty alleviation. The two terms were introduced through Presidential Instruction Program Number 5 of 1993, later known as the Inpres Disadvantaged Villages (IDV). Since then, the terms empowerment and poverty alleviation seem to be "twin brothers", which have always been a topic of discussion and keywords of development efforts.

The issue of community empowerment is very complicated and complex. Empowerment can be seen at different levels, namely from individuals and organizations or communities [27]. However, it remains a concern that the central concept of community empowerment is to mobilize local communities to meet their health and social needs and work cross-sectorally to solve local problems they experience [8].

The concept of community empowerment is a process that sees the importance of channelling or channelling power from a subject to an object. The empowerment process is defined as the acknowledgement of a specific subject to the ability or strength possessed by the object [28]. The goal to be achieved in this process is the shift of individual functions from the original object to the new subject. Thus, social relations will only be characterized by social connections between subjects and other subjects [29].

The thing that must be a concern is that community empowerment is the same as increasing community participation, community capacity, and community access to something [30]. Ideally, community empowerment should be designed so that it can meet the needs, abilities, desires, and behaviour of the community [31]. In this context, it is necessary to have local community attitudes that contribute to a better understanding of the needs and aspirations of local communities for the empowerment process [32].

\subsection{Quality of Alternative Business Training Model with Environmentally Based Community Empowerment for Farm Workers}

The model developed in this study is an alternative business training model based on environmental-based community empowerment for farmworkers. This training model was designed by researchers based on an analysis of the needs of farmworkers by adopting the teaching model proposed by [22]. In other words, this training model is a model that contains various guides in teaching how to manage rice waste into specific products.

Like a teaching model in general, this training model is also supported by several model components. Several components in this training model are (1) syntax, (2) social system, (3) reaction principle, (4) support system, and (4) instructional impact \& accompaniment. This training model has five stages of training that were later shortened to ASRIL: advice, self-development, reinforcement, innovation, and learning community.

Before being widely used, this training model must go through several trials to determine its quality. [33] states that in testing the quality of a product resulting from research and development, it must pass three test phases, namely validity, practicality, and effectiveness tests. A validity test is a test aimed at a group of experts to assess the quality of the product. Second, a practicality test is conducted to evaluate how practical the training model is based on users' perspectives, both participants and instructors. Finally, the effectiveness test was carried out by looking at the test results at the beginning and end of the session related to the training material.

\section{METHODS}

\subsection{Research Design \& Participants}

This research is part of the research and development process by adopting the model of [34]. In other words, this article reviews explicitly the quality test of the training model that has been developed by previous researchers, which includes tests of validity, practicality, and effectiveness. The three tests are standard in determining product quality through research \& development design [33].

There are two groups of participants involved in this study, namely experts and farmworkers. The experts appointed to assess the product of this research are lecturers in agriculture and the environment from several campuses with a minimum teaching period of 10 years. The number of participants from this expert group is three people and has a minimum 
educational doctoral background.

In addition to the expert group, this study also involved farm labourers from two sub-districts in Wajo Regency, South Sulawesi, Indonesia, namely Pammana and Tanasitolo sub-districts. There were 15 farm labourers engaged by using the purposive sampling technique in determining it. This technique is a sample selection technique based on specific considerations following the theme and research objectives. This research is part of the research and development process by adopting the model [34]. In other words, this article reviews explicitly the quality test of the training model that has been developed by previous researchers, which includes tests of validity, practicality, and effectiveness. The three tests are standard in determining product quality through research \& development design [33].

There are two groups of participants involved in this study, namely experts and farmworkers. The experts appointed to assess the product of this research are lecturers in agriculture and the environment from several campuses with a minimum teaching period of 10 years. The number of participants from this expert group is three people and has a minimum educational doctoral background.

In addition to the expert group, this study also involved farm labourers from two sub-districts in Wajo Regency, South Sulawesi, Indonesia, namely Pammana and Tanasitolo sub-districts. There were 15 farm labourers engaged by using the purposive sampling technique in determining it. This technique is a sample selection technique based on specific considerations by the theme and research objectives. [35].

\subsection{Data Collection}

\section{Product Validation Sheet}

Validation sheets are used to collect data from experts related to the assessment of development products. Several validation sheets used in this study were: (1) training model validation sheet, (2) instructor handbook validation sheet, (3) module validation sheet, (4) training video validation sheet, and (5) evaluation tool validation sheet. This validation sheet is designed using a Likert Scale with four assessment options, namely 4 for the highest score to 1 for the lowest score.

\section{Training Model Implementation Sheet}

In the practicality test, one of the instruments used is a training model implementation sheet. The researcher designed this sheet by providing four assessment indicators that the observer must score. The four indicators assessed in the implementation sheet of the training model are syntax indicators, social systems, reaction principles, and support systems.

\section{Farmworker Activity Observation Sheet}

To determine the level of practicality of the training model, the researchers also used farm labour activity sheets. This sheet is given to observers to assess the activities of farmworkers during the training process. This observation sheet consists of seven (7) main activities that the observer must observe, namely: (1) following the presentation of the training material, (2) completing the module by crossing out or underlining the parts that are considered necessary, (3) responding to the instructor's explanation by ask questions, comments, and suggestions, (4) pay attention to the presentation of agricultural industry waste management through video shows, (5) pay attention to feedback, (6) students think or pay attention to the explanations given by the instructor, and (7) participants look sleepy, daydreaming, or chatting.

\section{Farmer's Response Questionnaire}

Apart from the implementation sheet of the training model and the observation sheet on the activities of farmworkers, the researchers also used a questionnaire on farm workers' responses to determine the level of practicality of the training model. This questionnaire was given to the trainees at the last session they received the training materials. This questionnaire is designed by providing two alternative answer choices, namely "yes" and "no". In addition, this response questionnaire consists of six aspects of questions, namely: (1) responses to training, (2) responses to materials, (3) responses to modules, (4) responses to training videos, (5) responses to instructors, (6) the response to the comfort aspect in training.

\section{Knowledge Test}

A knowledge test is used to determine the level of understanding of farmworkers both before training (pretest) and after training (pretest). The types of questions used are statement questions designed with two alternative answers, namely "true" or "false". The questions consist of seven aspects with a total of 10 items for each aspect. The correct answer choice gets a score of 1 , and the wrong answer gets a score of 0 . The six aspects of the statement in the test are (1) land preparation, (2) planting, (3) maintenance, (4) fertilization, (5) pest control and disease, (6) harvest and post-harvest, and (7) utilization of agricultural waste. 


\subsection{Data Analysis}

Validity Test

Data from the validators were analyzed to determine the average score. After the average score was selected, the researcher matched it with the table of validity criteria. The validity criteria consist of four levels, namely: (a) very valid, (b) valid, (c) less valid, and (d) invalid. The validity criteria used can be seen in table 1.

Table 1. Criteria for product validity [36].

\begin{tabular}{cc}
\hline Rentang Skor & Category \\
\hline $3.5 \leq M \leq 4$ & Very valid \\
\hline $2.5 \leq M<3.5$ & Valid \\
\hline $1.5 \leq M<2.5$ & Less valid \\
\hline$M<1.5$ & Invalid \\
\hline
\end{tabular}

\section{Practicality Test}

Data from the observation sheet on the implementation of the training model was analyzed quantitatively by calculating the average score of two observers. After obtaining the average score, then it is compared with the criteria for implementing the model. The criteria for implementing the training model are grouped into three parts, namely: (1) fully implemented, (2) partially implemented, and (3) not implemented. In detail, the categories of implementation of the training model can be seen in table 2 .

Table 2. Criteria for implementing the training model [37].

\begin{tabular}{cc}
\hline Score Interval & Category \\
\hline $1.5 \leq M \leq 2.0$ & Implemented in its entirety \\
\hline $0.5 \leq M \leq 1.5$ & Partially implemented \\
\hline $0.0 \leq M \leq 0.5$ & Not implemented \\
\hline
\end{tabular}

Data on the practicality level were also obtained through questionnaires on responses from farmworkers. The collected questionnaire data were analyzed quantitatively by determining their positive reactions to the training model. The practicality criteria of the farmworkers' response questionnaires can be seen in table 3 .

Table 3. Criteria for the practicality of the training model [38].

\begin{tabular}{ccc}
\hline No. & Percentage Interval & Category \\
\hline 1. & $76-100 \%$ & Very practical \\
\hline 2. & $51-75 \%$ & Practical \\
\hline 3. & $26-50 \%$ & Practical enough \\
\hline 4. & $0-25 \%$ & Not practical \\
\hline
\end{tabular}

\section{Effectiveness Test}

The quality test of the training model is carried out by running an effectiveness test. This test aims to determine the quality of the training model by looking at the difference between the pretest and posttest scores. This test uses a quasiexperimental design with one group pretest-posttest. The research design used can be seen in table 4.

Table 4. Research design on effectiveness test

\begin{tabular}{cccc}
\hline \multicolumn{4}{c}{ One Group Pretest-posttest Design } \\
\hline Group & Pretest & Intervention & Posttest \\
\hline Farmworkers & $O 1$ & $X$ & $O 2$ \\
\hline
\end{tabular}

Information:

O1 : Pretest

O2 : Posttest

$\mathrm{X}$ : treatment with alternative business training models for farm workers with empowerment environment-based society 
Data from both test sessions, both pretest and posttest, were analyzed using SPSS version 23.00 software. The researcher ran a t-test to see the difference in pretest and posttest scores so that it can be concluded whether the developed training model can increase the knowledge of farmworkers.

\section{RESULTS}

\subsection{Validity of the Training Model}

Before collecting validity data from the validators, the researchers conducted a test to see the level of validity and reliability of the instrument. The six instruments tested included: (a) training model books, (b) instructor handbooks, (c) modules, (d) training videos, and (e) evaluation tools. Completely, the results of the validity and reliability of the research instruments can be seen in the following table 5 .

Table 5. The results of the validity \& reliability of the instrument

\begin{tabular}{cccccc}
\hline No. & Validation sheet items & $\boldsymbol{r}_{\boldsymbol{\alpha}}$ & Category & $\begin{array}{c}\text { Cronbach's } \\
\text { alpha }(\boldsymbol{\alpha})\end{array}$ & Category \\
\hline 1. & Training model book & .77 & Valid & 0.82 & Reliable \\
\hline 2. & Instructor book & .76 & Valid & 0.85 & Reliable \\
\hline 3. & Module & .80 & Valid & 0.80 & Reliable \\
\hline 4. & Training videos & .85 & Valid & 0.90 & Reliable \\
\hline 5. & Evaluation tool & .86 & Valid & 0.87 & Reliable \\
\hline
\end{tabular}

Table 6. The results of the validation of the training model book

\begin{tabular}{|c|c|c|c|c|c|c|}
\hline \multirow{2}{*}{ No. } & \multirow[t]{2}{*}{ Rated aspect } & \multicolumn{3}{|c|}{ Validator } & \multirow{2}{*}{$X$} & \multirow{2}{*}{ Category } \\
\hline & & $V 1$ & $V 2$ & V3 & & \\
\hline 1. & Theory from several aspects & 3.17 & 3.50 & 3.33 & 3.33 & Valid \\
\hline 2. & Syntax & 3.00 & 3.80 & 3.80 & 3.53 & Very valid \\
\hline 3. & Social system & 3.20 & 3.20 & 3.40 & 3.27 & Valid \\
\hline 4. & Reaction principle & 3.00 & 3.38 & 3.75 & 3.38 & Valid \\
\hline 5. & Support system & 3.50 & 4.00 & 3.50 & 3.67 & Very valid \\
\hline 6. & Instructional impact \& accompaniment & 3.00 & 4.00 & 3.50 & 3.50 & Very valid \\
\hline 7. & Implementation of training & 3.33 & 3.33 & 3.67 & 3.44 & Valid \\
\hline 8. & Training environment \& management tasks & 3.00 & 3.00 & 3.75 & 3.25 & Valid \\
\hline \multirow[t]{2}{*}{9.} & Evaluation & 3.00 & 3.00 & 3.60 & 3.20 & Valid \\
\hline & Average & 3.13 & 3.47 & 3.59 & 3.40 & Valid \\
\hline
\end{tabular}

Furthermore, the training tools that are also validated are modules. The validation results of the training module stated that all aspects assessed by the experts were categorized as 'very valid'. This can be seen from the cumulative average score, which reached 3.63 and was in the range of $3.5<\mathrm{M}<4.0$. The results of the validation of the training module can be seen in table 7.

Table 7. Validation of training modules

\begin{tabular}{|c|c|c|c|c|c|c|}
\hline \multirow{2}{*}{ No. } & \multirow{2}{*}{ Rated aspect } & \multicolumn{3}{|c|}{ Validity } & \multirow[t]{2}{*}{$X$} & \multirow[t]{2}{*}{ Category } \\
\hline & & $V 1$ & $V 2$ & $V 3$ & & \\
\hline 1. & Module format & 3.86 & 3.71 & 3.29 & 3.62 & Very valid \\
\hline 2. & Module Contents & 3.83 & 3.50 & 3.33 & 3.56 & Very valid \\
\hline 3. & Language \& writing & 3.83 & 3.33 & 3.33 & 3.50 & Very valid \\
\hline 4. & Illustration \& image support & 4.00 & 3.75 & 3.25 & 3.67 & Very valid \\
\hline 5. & Benefits \& uses & 4.00 & 4.00 & 3.50 & 3.83 & Very valid \\
\hline & Aspect Average & 3.90 & 3.66 & 3.34 & 3.63 & Very valid \\
\hline
\end{tabular}


Table 8. Instructor handbook validation results

\begin{tabular}{ccccccc}
\hline \multirow{2}{*}{ No. } & Rated aspect & \multicolumn{3}{c}{ Validity } & \multirow{2}{*}{$\boldsymbol{X}$} & \multirow{2}{*}{ Category } \\
\cline { 2 - 5 } & & $\boldsymbol{V 1}$ & $\boldsymbol{V 2}$ & $\boldsymbol{V 3}$ & & \\
\hline 1. & Instructor handbook format & 2.80 & 3.40 & 3.80 & 3.33 & Valid \\
\hline 2. & Book contents & 3.33 & 3.50 & 3.50 & 3.44 & Valid \\
\hline 3. & Language \& writing & 3.33 & 3.50 & 3.67 & 3.50 & Valid \\
\hline 4. & Time & 4.00 & 4.00 & 3.50 & 3.83 & Very valid \\
\hline 5. & Uses \& benefits & 4.00 & 3.50 & 3.50 & 3.67 & very valid \\
\hline & Aspect average & 3.49 & 3.58 & 3.59 & 3.56 & very valid \\
\hline
\end{tabular}

Table 8 above is the result of the validation of the instructor's handbook from the three validators. There are two aspects of the assessment in the instructor's guide that get a high score: the time aspect of 3.83 and the usability/benefit aspect of 3.67. In addition, three other elements of book format, book content, and language \& writing, are in the 'valid' category. Overall, the cumulative average score of instructor handbook validation is 3.56 and is categorized as 'very valid'.

Table 9. Validation of training videos

\begin{tabular}{ccccccc}
\hline \multirow{2}{*}{ No. } & Rated aspect & \multicolumn{3}{c}{ Validity } & \multirow{2}{*}{$\boldsymbol{X}$} & Category \\
\cline { 3 - 6 } & Format & $\boldsymbol{V 1}$ & $\boldsymbol{V} 2$ & $\boldsymbol{V} 3$ & & \\
\hline 1. & Language & 3.00 & 3.67 & 3.33 & 3.33 & Valid \\
\hline 2. & Illustration & 3.00 & 4.00 & 3.67 & 3.56 & Very valid \\
\hline 3. & Contents & 2.75 & 3.50 & 3.75 & 3.33 & Valid \\
\hline 4. & Aspect average & 3.06 & 3.71 & 3.65 & 3.47 & Valid \\
\hline
\end{tabular}

Table 10. Validity of the evaluation instrument test

\begin{tabular}{ccccccc}
\hline \multirow{2}{*}{ No. } & Rated aspect & \multicolumn{3}{c}{ Validity } & \multirow{2}{*}{$\boldsymbol{N}$} & \multirow{2}{*}{ Category } \\
\cline { 3 - 5 } & & $\boldsymbol{V 1}$ & $\boldsymbol{V 2}$ & $\boldsymbol{V 3}$ & & \\
\hline 1. & Question Material & 3.00 & 3.75 & 3.25 & 3.33 & Valid \\
\hline 2. & Construction & 3.50 & 3.75 & 4.00 & 3.75 & Very valid \\
\hline 3. & Language & 3.00 & 3.67 & 3.33 & 3.33 & Valid \\
\hline 4. & Time & 3.00 & 4.00 & 4.00 & 3.67 & Very valid \\
\hline & Aspect Average & 3.13 & 3.79 & 3.65 & 3.52 & Very valid \\
\hline
\end{tabular}

Other validated training tools are training videos and evaluation instrument tests. The validation results on the training video show an average score of 3.47 and are categorized as 'valid'. In contrast to the training video, the evaluation instrument test achieved an average of 3.52 and could be classified as a 'very valid' level. Thus, both training tools are suitable for use by farm labourers. In total, the results of the validation of the training video. And the test of the evaluation instrument can be seen in tables 9 and 10 .

\subsection{Practicality of the Training Model}

Its level of practicality also measures the quality of the training model. For the usefulness of the training model, the researcher used an observation sheet to implement the model. And a questionnaire on the responses of farmworkers. From the observations made by two observers during the training process, it was concluded that the training model for farm labourers was categorized as fully implemented with an average score of 1,975 from a total score of 2 . This indicates that the training model has been classified as practical. The results of observations on the implementation of this training model can be seen in table 11 . 
Table 11. Results of the implementation of the training model

\begin{tabular}{cccc}
\hline No. & Observed aspects & Average Score & Category \\
\hline $\mathbf{1 .}$ & Syntax & 1.99 & Implemented in its entirety \\
\hline 2. & Social system & 1.98 & Implemented in its entirety \\
\hline 3. & Reaction principle & 1.93 & Implemented in its entirety \\
\hline 4. & Support system & 2.00 & Implemented in its entirety \\
\hline & Total & 1.975 & Implemented in its entirety \\
\hline
\end{tabular}

Furthermore, the practicality of the training model is also obtained from the response data of farmworkers to the model. From the questionnaire responses of farmworkers that have been distributed, information is received that their average positive response to the training model is $97.56 \%$. This means that almost all workers stated that the training, materials, modules, videos, instructors and the comfort factor during the training process were considered good. Specifically, the results of the response of farmworkers to the training model can be seen in table 12 .

Table 12. Participants' responses to the training model

\begin{tabular}{cccc}
\hline \multirow{2}{*}{ No } & \multirow{2}{*}{ Aspect } & \multicolumn{2}{c}{ Participant Response } \\
\cline { 2 - 4 } & Response to training & Yes (\%) & No (\%) \\
\hline 1. & Response to material & $96.67 \%$ & $0 \%$ \\
\hline 2. & Response to module & $96.11 \%$ & $3.33 \%$ \\
\hline 3. & Response to video & $97.78 \%$ & $2.89 \%$ \\
\hline 4. & Response to instructor & $97.33 \%$ & $2.67 \%$ \\
\hline 5. & Response to comfort & $97.50 \%$ & $2.50 \%$ \\
\hline 6. & Average & $97.56 \%$ & $2.44 \%$ \\
\hline
\end{tabular}

\section{Effectiveness of the Training Model}

The training model's effectiveness was obtained in the pretest and posttest of knowledge of farmworkers. Furthermore, the results were analyzed quantitatively using SPSS 23.00. The results of the t-test analysis can be seen in table 13 .

\begin{tabular}{|c|c|c|c|c|c|c|c|c|c|}
\hline & & \multicolumn{5}{|c|}{ Paired Differences } & \multirow[b]{3}{*}{$t$} & \multirow[b]{3}{*}{$d f$} & \multirow{3}{*}{$\begin{array}{c}\text { Sig. } \\
(2- \\
\text { tailed })\end{array}$} \\
\hline & & & & & \multicolumn{2}{|c|}{$\begin{array}{c}95 \% \\
\text { confidence } \\
\text { interval of the } \\
\text { difference }\end{array}$} & & & \\
\hline & & Mean & $\begin{array}{c}\text { Std. } \\
\text { deviati } \\
\text { on }\end{array}$ & $\begin{array}{c}\text { Std. } \\
\text { Error } \\
\text { Mean }\end{array}$ & Lower & Upper & & & \\
\hline Pair-1 & Pretest-posttest & -12.267 & 2.651 & .484 & -13.257 & -11.277 & -25.34 & 29 & .000 \\
\hline
\end{tabular}

Table 13 is a paired samples test with information that the probability (p) with the symbol sig. (2-tailed) for pair-1 (pretest-posttest), the experimental group was 0.000 . Based on the provisions, if the probability value is less than 0.05 , it can be concluded that there is a significant difference between the two scores. It means that alternative business training models with environmental-based community empowerment for farmworkers increase their knowledge in managing agricultural waste.

\section{DISCUSSION}

This training model is designed to manage agricultural waste into an alternative business other than rice cultivation. The exciting thing about this training model is the involvement of the surrounding community in supporting the achievement of this training. The participation of community empowerment is solely aimed at increasing the dignity of the layers of society that are classified as unable to escape from poverty [39]. This is in line with [40] statement, which states that community empowerment provides opportunities for underprivileged communities to increase their independence and self-esteem.

Talking about community empowerment, of course, relates to specific areas that need the program. Agriculture is one area that requires support from the community empowerment movement. This is because agriculture is a field of work that 
most people occupy. [41] stated that mapping of community assistance or empowerment is needed in four areas, namely coastal, forestry, rice fields, and mountains. For this reason, it is necessary to have strategic policies that are designed and adapted to the needs that have a direct impact on improving the community's economy [24].

The training model for farmworkers that the researcher has designed is then tested for quality. Testing the quality of this research product refers to the test conducted by [33], divided into three parts: the test of validity, practicality, and effectiveness. The validity of a training/learning model is determined by a situation that states that the product has met the needs, is state of the art, has a strong theoretical foundation, and there is consistency between model components [42]. Validation is carried out to know the suitability of the theory with various other aspects [43]. These aspects are learning activities, learning steps, and teaching methods.

Practicality is an essential aspect in determining the quality of the training model that researchers have developed. The results of this study indicate that this training model is practically based on the responses and activities of farmworkers during the training process. The training model is declared practical if the instructor and participants/users can use the model easily (under normal conditions) [44]. In addition, the practicality of the training model is also seen from the user's activities in applying it during the training/learning process without experiencing significant obstacles [45] [46].

Besides being declared valid and practical, this training model is also declared effective in increasing the knowledge of farmworkers. Effectiveness is usually determined by giving a pretest and posttest and then seeing the extent of the difference. [47] stated that effectiveness could be seen from the responses given by trainees who meet the criteria of 'good' or 'very good'. On the other hand, [48] state that many factors can affect the effectiveness of a training/learning model, including (1) motivation, (2) attitude, (3) training style, (4) facilitator openness/instructor, (5) environment, and (6) basic skills.

\section{CONCLUSION}

Agriculture as one of the fields of work that most Indonesians are engaged in has not improved their welfare. This happens because many farmers have the status of farm labourers and do not carry out other business activities. This means that they are only focused on cultivating morning plants that have not met their needs. For this reason, natural solutions are needed in helping these farmworkers, one of which is by developing alternative business training models with environmental-based community empowerment.

Before being widely used, the training model product must measure the level of quality it has. In determining the grade in question, there are three tests carried out by researchers, namely the validity, practicality, and effectiveness tests. The results showed that this training model proved valid based on the assessments carried out by experts. In addition, this training model is also stated to be practically based on the responses of the users (farm workers) and the activities of farm workers during the training process, which the observers observed. Finally, this training model was also declared effective based on statistical tests from the pretest and posttest data on the knowledge of farmworkers. This means that this training model can increase the knowledge of farmworkers about agricultural waste management.

\section{REFERENCES}

[1] Breman J. Control of land and labour in colonial Java. Holland: Foris Publications; 1983.

[2] Akbar AJ, Yuiana S, Marwa T. Pengaruh nilai tukar rupiah, suku bunga sbi, dan inflasi terhadap indeks harga saham gabungan (ihsg) sektor pertanian di bursa efek Indonesia. Jurnal Ekonomi. 2016;14(2):47-53.

[3] Badan Pusat Statistik. Statistik upah buruh tani di perdesaan [Internet]. 2020 [cited 2021 Jun 12]. Available from: www.bps.go.id

[4] Warto W. Kondisi kemiskinan petani dan upaya menanggulanginya. Jurnal PKS. 2015;14(1):20-9.

[5] Todaro MP, Smith SC. Pembangunan ekonomi di dunia ketiga. Jakarta, Indonesia: Erlangga; 2011.

[6] Yacoub Y, Mutiaradina H. Analisis kesejahteraan petani dan kemiskinan perdesaan di indonesia. In: Prosiding Seminar Akademik Tahunan Ilmu Ekonomi dan Studi Pembangunan. 2020. p. 92-102.

[7] Wulandari E, Ernah E, Supyandi D. Penguatan kemampuan manajerial petani melalui pelatihan dan pendampingan pencatatan finansial usaha tani di kabupaten Cianjur. Dharmakarya: Jurnal Aplikasi Ipteks untuk Masyarakat. 2017;6(3):189-92.

[8] Kasmel A, Andersen PT. Measurement of community empowerment in three community programs in Rapla (Estonia). International Journal of Environmental Research and Public Health. 2011;8(3):799-817.

[9] Laverack G, Wallerstein N. Measuring community empowerment: A fresh look at organizational domains. Health Promot International. 2001;16(2):179-85.

[10] Sayer J, Sunderland T, Ghazoul J, Pfuna JL, Shell D. Ten principles for landscape approach to reconciling agriculture, conservation, and other competiting land uses. In: Proceedia of The National Academy of Sciences. USA; 2013. 
[11] Yu J, Wu J. NThe sustainability of agricultural development in China: The agriculture-environment nexus. Sustainability. 2018;10(1776):1-17.

[12] Awad Y andi, Labatar SC. Pemanfaatan smartphone sebagai sumber informasi pertanian oleh kelompok tani di kampung Desay distrik Prafi kabupaten Manokwari. Jurnal Triton. 2017;8(2):27-37.

[13] Awar A, Dammar B, Nongkeng H. Pengaruh pendidikan dan pelatihan (diklat) tenaga penyuluh terhadap peningkatan produksi tanaman pangan di kabupaten Bulukumba. YUME: Journal of Management. 2019;2(3):1-12.

[14] Rahmiati F, Amin G, German E. Pelatihan pemanfaatan limbah padi menjadi arang sekam untuk menambah pendapatan petani. Agrokreatif: Jurnal Ilmiah Pengabdian kepada Masyarakat. 2019;5(2):159-64.

[15] Rahman YMD, Hendrawijaya AT. Dampak program pelatihan kelompok santri tani milenial dalam mewujudkan keberdayaan santri di pondok pesantren baitul hikmah kecamatan Tempurejo kabupaten Jember. Learning Community: Jurnal Pendidikan Luar Sekolah. 2020;4(2):31-4.

[16] Mgendi G, Mao S, Qiao F. Is a training program sufficient to improve the smallholder farmers' productivity in Africa? Empirical evidence from a Chinese agricultural technology demonstration center in Tanzania. Sustainability (Switzerland). 2021;13(3):1-23.

[17] Hlela Z. Learning through participation: Towards defining adult learning in an African rural village context. Community Development Journal. 2019;54(4):660-76.

[18] Worku BT. Effectiveness of modular training of farmers' training centers: The case of Mi'eso Woreda, Oramia Region, Ethiopia. Haramaya University; 2010.

[19] Merriam SB. Adult learning theory: Evolution and future directions. PAACE Journal of Lifelong Learning. 2017;26(1):21-37.

[20] Hrebin N, Hrabovska S, Karkovska R, Vovk A. Applying Benjamin Bloom's taxonomy ideas ina dult leraning. Journal of Education Culture and Society. 2020;11(1):61-72.

[21]Bode E, Gold R. Adult training in the digital age. Economics: The Open-Access, Open-Assessment E-journal. 2018;12(1):1-14.

[22] Joyce B, Weil M, Emily Calhoun. Models of Teaching. Delapan. Yogyakarta: Pustaka Pelajar; 2011.

[23] Suratiyah K. Ilmu Usaha tani (edisi revisi). Penebar Swadaya Grup; 2015.

[24] Mubyarto. Pengantar Ekonomi Pertanian. Jakarta: Lembaga Penelitian dan Pendidikan dan Penerapan Ekonomi Sosial; 1989.

[25] Soekarwati. Analisis Usahatani. Jakarta: Universitas Indonesia Press; 1995.

[26] Razak MRR, Sofyan B. Role of village-owned enterprises in farming community empowerment. International Journal of Advanced Science and Technology. 2020;29(6):684-91.

[27]Zimmerman MA. Empowerment theory: Psychological, organizational and community levels of analysis. In: Rappaport J, Seidman E, editors. Handbook of community psychology. Kluwer: Kluwer Academic Publisher; 2000. p. 43-63.

[28] Permadi B. Community empowerment and farmer poverty reduction in developing countries. Journal of Public Administration Studies. 2019;4(1):9-13.

[29] Noventri IA. Farmer community empowerment in Indonesia. Jurnal Ilmiah Administrasi Publik. 2017;3(3):242-8.

[30] Ahmad MS, Abu Talib NB. Analysis of community empowerment on projects sustainability: Moderating role of sense of community. Social Indicators Research. 2014;119(2):1039-56.

[31] Infield M, Namara A. Community attitudes and behaviour towardsconservation: An assessmnet of a community conservation programme around lake Mbure national park, Uganda. Oryx. 2001;35:48-60.

[32] Setiajiati F, Hardjanto, Hendrayanto. Strategies of community empowerment to manage protection forest sustainably. Jurnal Manajemen Hutan Tropika. 2017;23(2):71-80.

[33] Nieveen N. Prototyping to Reach Product Quality. In: Akker J Van Den, Branch RM, Gustafson K, Nienke Nieveen, editors. Design Approaches and Tool in Education and Training. Boston: Kluwer; 1999.

[34] Borg WR, Gall DM. Educational Research. New York: Longman; 1989.

[35] Helaluddin H, Wijaya H. Analisis Data Kualitatif: Sebuah Tinjauan Teori \& Praktik. Makassar: Sekolah Tinggi Filsafat Jaffray; 2019.

[36] Supartini T, Weismann IThJ, Wijaya H, Helaluddin Helaluddin. Development of Learning Methods through Songs and Movements to Improve Children's Cognitive and Psychomotor Aspects. European Journal of Educational Research. 2020;9(4):1615-33.

[37] Hasmawaty H, Syam H, Saman A. Validity , Practicality, and Effectiveness: The Last Step in Development of Entrepreneurship Education Based Role-Playing for Kindergarten. Universal Journal of Educational Research. 2020;8(12):8092-101.

[38] Jayanti RD, Syahrial Z, Situmorang R. Pegembangan model pelatihan teknis bagi penyuluh keluarga berencana untuk meningkatkan kompetensi melaksanakan pembinaan kader institusi masyarakat pedesan/perkotaan. Jurnal Teknologi Pendidikan. 2019;21(1):56-74.

[39] Theresia A. Pembangunan berbasis masyarakat. Bandung, Indonesia: Alfabeta; 2014.

[40] Laksono BA. The community empowermwnt through social and educational institutions. Jurnal Pendidikan Humaniora. 2018;6(3):115-22. 
[41] Rahmat A, Izudin A. Impact evaluation of community empowerment programs with the farmer managed extension model. European Research Studies Journal. 2018;21(2):225-35.

[42] Nieveen N, McKenney S, Akker V Den. Educational design research. New York: Routledge; 2007.

[43] Gravemeijer K, Cobb P. Design research form in a learning design perspective. In: Akker J Van Den, Gravenmeijer K, McKenney S, Nieveen N, editors. Educational design research. London, UK: Routledge; 2006. p. 17-51.

[44]4Yazid A. Kevalidan, Kepraktisan, dan Efek Potensial Suatu Bahan Ajar. Palembang: Pascasarjana Universitas Sriwijaya; 2011.

[45] Syahputra HH, Hasrudin H, Ely D. The development of biology interactive learning media based macromedia flash in the material of digestive system of human at class xi sma/ma. In: Proceeding Biology Education Conference. 2015. p. 636-43.

[46] Mustami MK, Syamsudduha S, Safei S, Ismail MI. Validity, Practically, and Effectiveness Development of Bilogy Textbooks Integrated with Augument Reality on High School Students. International Journal of Technology Enhanced Learning. 2019;11(2):187-200.

[47] Jean P, Sucihatiningsih DWP, Rusdiarti R. Model pelatihan vokasional berbasis pemanfaatan rebung bambu pada masyarakat desa Paloan kecamatan Sengah Tenil kabupaten Landak. Journal of Vocational and Career Education. 2017;2(1):70-8.

[48] Punia BK, Kant S. A Review of factors affecting training effectiveness vis-a-vis managerial implications and future research directions. Journal of advanced Research in Management and Social Sciences. 2013;2(1):151-64. 